\title{
Compatibility of Acaricide Residues with Phytoseiulus persimilis and Their Effects on Tetranychus urticae
}

\author{
Kenneth W. Cote, Edwin E. Lewis, and Peter B. Schultz \\ Department of Entomology, Virginia Polytechnic Institute and State University, \\ 216 Price Hall, Mail Code 0319, Blacksburg, VA 24061 \\ Additional index words. biological control, pesticides, predator, spider mites, toxicity
}

\begin{abstract}
The twospotted spider mite, Tetranychus urticae Koch, is a serious pest of many nursery crops. Regular acaricide applications are required to maintain acceptable population levels of this pest. Phytoseiulus persimilis Athias-Henriot is a commercially available predator used to control $T$. urticae populations. The effects of acaricide residues were tested on $P$. persimilis and $T$. urticae using a leaf disk system. Both species were exposed to residues for 24 hours 1, 3, 7, and 14 days after acaricide application. Abamectin, Gowan 1725, hexythiazox, horticultural oil, neem oil, pyridaben, and spionosyn residues caused no mortality to $P$. persimilis $1,3,7$, or 14 days after application. Chlorfenapyr was harmful to both species at all times after application. Bifenthrin residue was toxic to $P$. persimilis at all times after application, but was only harmful to $T$. urticae up to one week after application. Tetranychus urticae mortality from Gowan 1725, horticultural oil, and neem oil residues was significantly greater than the control 24 hours after application, but not thereafter. Tetranychus urticae mortality from hexythiazox and spinosad residues was not significantly greater than the control. Proper pesticide selection may create favorable conditions for release of $\boldsymbol{P}$. persimilis and reduce acaricide dependency.
\end{abstract}

The twospotted spider mite, Tetranychus urticae Koch, is a serious pest of many greenhouse plants, nursery-grown ornamentals, and field crops. Twospotted spider mite damage may include webbing, fine stippling, leaf yellowing, leaf drop, and even plant death (Helle and Sabelis, 1985). Species in its host range include numerous herbaceous and woody landscape plants such as rose, ivy, and winged euonymus (Johnson and Lyon, 1991). Female $T$. urticae can develop from egg to adult in $\approx 6.5 \mathrm{~d}$ at $30{ }^{\circ} \mathrm{C}$ (Sabelis, 1981), and females can lay as many as 60 eggs in $5 \mathrm{~d}$ (Helle and Sabelis, 1985). The expense of new acaricides and the loss of production time associated with pesticide applications has made frequent acaricide applications costly. Development of resistance by T. urticae to numerous acaricides has caused difficulties in controlling outbreaks (Carbonaro et al., 1986). These conditions have raised interest by growers to introduce predatory phytoseiid

Received for publication 9 July 2001. Accepted for publication $29 \mathrm{Jan}$. 2002. This paper is a portion of a thesis submitted to Virginia Polytechnic Institute and State Univ. for the MS in Entomology by Kenneth W. Cote. We thank the Gloeckner Foundation for its support of this research, Virginia Agricultural Experiment Station, The Virginia Agricultural Council and the Virginia Nursery and Landscape Association for financial support. We also thank Nancy Boles, Scotty Bolling, Josh Thomberg, and Janet Ashley for their laboratory assistance, and Michael Raupp and Daniel Gilrein for critically reviewing the manuscript. Mention of a trademark, proprietary product, or vendor does not constitute a guarantee or warranty of the product by Virginia Tech and does not imply its approval to the exclusion of other products or vendors that also may be suitable. mites to manage twospotted spider mites to reduce their need for acaricide applications (Sabelis, 1981).

Phytoseiulus persimilis Athias-Henriot can be effective as one of many tools of an integrated pest management program for T. urticae. Trials conducted in Florida, which used Phytoseiulus persimlis to control twospotted spider mite on Crotons and Areca palms, reduced the number of acaricide applications by $87 \%$ to $92 \%$ in Croton, and $100 \%$ in Areca palms (Cashion et al. 1994). Releases of $P$. persimilis in interiorscapes to suppress mite populations have performed with varying degrees of success (Lindquist, 1981). Despite successful suppression of T. urticae, limitations to the effectiveness of $P$. persimilis arise under certain conditions in which their fecundity may be reduced. The optimum conditions for rapid population development of $P$.persimilis is a temperature of $27{ }^{\circ} \mathrm{C}$ and relative humidity (RH) of $60 \%$ to $85 \%$ (Stenseth, 1979). A temperature of $27{ }^{\circ} \mathrm{C}$ with $\mathrm{RH}<40 \%$ reduces the reproductive rate of $P$. persimilis by increasing egg mortality (Stenseth, 1979). This is a significant disadvantage because most greenhouses have temperatures and humidity levels that are outside these optima for part of the day. Another limitation to $P$. persimilis effectiveness is related to T. urticae density. As $T$. urticae density increases, $P$. persimilis predation becomes less likely to provide adequate suppression (Helle and Sabelis, 1985). Trumble and Morse (1993) demonstrated that suppression was achieved by releasing $P$. persimilis before $T$. urticae reach threshold levels that warrant chemical treatment. After threshold levels are surpassed, predator re- lease combined with compatible acaricides is more effective than using chemical or biological control tactics alone.

To combine $P$. persimilis with acaricide applications, chemical residues must be nontoxic to the predators. The effects of chemical classes on $P$. persimilis from most harmful to least harmful are organophosphates, pyrethroids, organochlorines, and carbamates (Pratt and Croft, 2000). However, the effects of individual products and formulations can vary greatly. Our objective was to determine the toxicity of residues of 10 new or commonly used acaricides to $P$. persimilis $1,3,7$, and $14 \mathrm{~d}$ after application. In addition, residual toxicity to $T$. urticae was recorded.

\section{Materials and Methods}

Twospotted spider mite colonies were maintained on lima beans (Phaseolus lunatus) at $30^{\circ} \mathrm{C}$ and 14:10 (L:D) photoperiod. The colony originated from an infested rose plant that was purchased at a local nursery. Rearing cages were $20 \times 40 \times 30$-cm Plexiglas boxes with an open top, fitted with thrips-proof screening. A ring of double-sided sticky tape on the outside rim and petroleum jelly on the inside rim prevented mite escape and contamination of colonies.

Acaricides were mixed with tap water at recommended rates and applied with a hand sprayer to whole bean plants under a fume hood (Table 1). Control plants were left unsprayed. Plants were left in the fume hood 30-45 min until leaf surfaces dried. Treated plants were placed under high intensity discharge (HID) lights with $250 \mathrm{fc}, 14: 10$ (L:D) photoperiod without overhead watering. Twenty leaf disks, each with a surface area of $\approx 10 \mathrm{~cm}^{2}$, were cut from plants of each treatment 1, 3, 7, and $14 \mathrm{~d}$ after application.

Survival tests were conducted on treated and control leaves using a modified Huffaker cell system (Huffaker, 1948; Lester et al., 1999; Munger, 1942). The cells were made from three $7.6 \times 7.6 \times 0.6 \mathrm{~cm}$ Plexiglas pieces bolted together like a sandwich. A $4.5-\mathrm{cm}$ diameter hole in the middle piece of Plexiglas created a small chamber in which the assay was performed.

Phytoseiulus persimilis adults were obtained from Koppert Biological (Ann Arbor, Mich.). After arrival, predators were brushed into a container of bean leaves infested with $T$. urticae. The predators were allowed to feed on prey for $18-24 \mathrm{~h}$ before testing. One $P$. persimilis adult was placed on the leaf disk in each modified Huffaker cell with two $T$. urticae adults to provide food for the predators. Cells were closed immediately after mite introduction. The total number of mites that died in all cells in each treatment was recorded after $24 \mathrm{~h}$. Temperatures averaged $28^{\circ} \mathrm{C}$ with a range of 25.2 to $32.5^{\circ} \mathrm{C}$ during the test period. For each material tested, mite mortality was compared on 20 nontreated leaf disks and 20 treated leaf disks for each time period. Data were analyzed by contingency table $(\alpha=0.05)$. Two-week-old resi- 
Table 2. Common and trade names, and application rates of acaricides tested

\begin{tabular}{lccc}
\hline \hline Common name & Trade name + formulation & Manufacturer & Mix rate \\
\hline Abamectin & Avid 0.15 EC & Novartis, Greensboro, N.C. & $4 \mathrm{oz} / 100 \mathrm{gal}$ \\
Bifenthrin & Talstar GH 0.67F & FMC, Philadelphia, Pa. & $40 \mathrm{oz} / 100 \mathrm{gal}$ \\
Chlorfenapyr & Pylon 2SC & American Cyanimid, Parsippany, N.J. & $5.2 \mathrm{oz} / 100 \mathrm{gal}$ \\
Gowan 1725 & Gowan 1725 0.1\% EC & Gowan, Yuma, Ariz. & $20 \mathrm{oz} / 100 \mathrm{gal}$ \\
Hexythiazox & Hexygon 50 WP & Gowan, Yuma, Ariz. & $1.5 \mathrm{oz} / 100 \mathrm{gal}$ \\
Horticultural oil & Sunspray Ultra-Fine & Sun Company, Philadelphia,Pa. & $250 \mathrm{oz} / 100 \mathrm{gal}$ \\
Neem oil & Triact 70 EC & Thermotrilogy Corporation, Columbia, Md. & $250 \mathrm{oz} / 100 \mathrm{gal}$ \\
Pyridaben & Sanmite 75 WP & BASF Corp., Research Triangle Park, N.C. & $4 \mathrm{oz} / 100 \mathrm{gal}$ \\
Spinosad & Conserve SC & Dow AgroSciences, Indianapolis, Ind. & $600 \mathrm{~mL} / 100 \mathrm{gal}$ \\
\hline
\end{tabular}

dues were not tested when mortality from residues was not significantly greater than controls for 1-week-old residues.

\section{Results}

The duration of acaricide residue toxicity varied among the compounds tested. Mortality of $P$. persimilis from exposure to residues of bifenthrin and chlorfenapyr was significantly greater than observed on the controls $1,3,7$, and $14 \mathrm{~d}$ after application. Phytoseiulus persimilis mortality on leaf disks treated with abamectin, Gowan 1725, hexythiazox, horticultural oil, neem oil, pyridaben and spinosad was not significantly greater than on untreated leaf disks at any time after application (Fig. 1A-D).
The response of $T$. urticae to residue exposures was more variable than that of $P$. persimilis. Tetranychus urticae mortality from chlorfenapyr residues was significantly greater than the control 1, 3, 7, and $14 \mathrm{~d}$ after application. Even after 2 weeks, chlorfenapyr residues caused $55 \%$ mortality to adult $T$. urticae compared to $6 \%$ mortality in the control. Tetranychus urticae mortality from bifenthrin and abamectin residues was not significantly greater than the control $1 \mathrm{~d}$ after application. However, T. urticae mortality for both bifenthrin and abamectin residues was significantly greater than the control 3, 7, and $14 \mathrm{~d}$ after application. Tetranychus urticae mortality caused by Gowan 1725, horticultural oil, and neem oil residues was significantly greater than the control $24 \mathrm{~h}$ after application but not at the other times tested. Tetranychus urticae mortality from hexythiazox and spinosad residues was not significantly greater than the control at any time tested (Fig. 2A-D).

\section{Discussion}

Our objective was to determine an aspect of compatibility between selected acaricides and release of predatory mites for management of T. urticae. For our purposes, a compatible acaricide can be defined as a product that has a residue that does not kill $P$. persimilis. The level of compatibility will usually depend, at least partly, on the post application interval. We measured toxicity of acaricide residues to commercially available P. persimilis. We did not consider sublethal
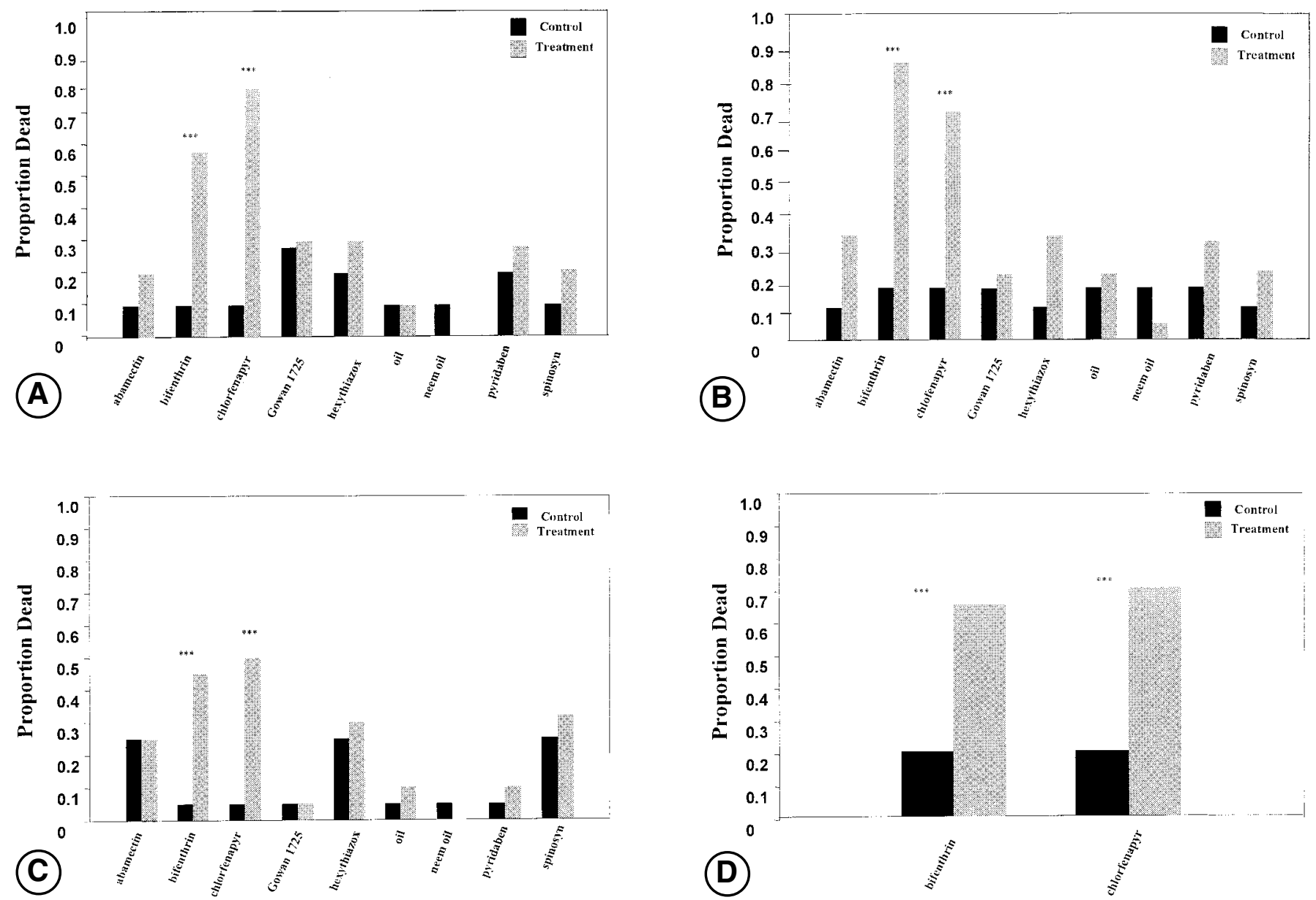

Fig. 1. Residue toxicity to Phytoseiulus persimilis (A) $1 \mathrm{~d}$ after application, (B) $3 \mathrm{~d}$ after application, (C) $7 \mathrm{~d}$ after application, and (D) $14 \mathrm{~d}$ after application. *** Indicates significant difference $(\alpha=0.05)$ between treatments and control. 
effects, which can occur from acaricide residues (Oomen et al., 1991).

Exposure to abamectin, Gowan 1725, hexythiazox, horticultural oil, neem oil, pyridaben, and spinosad residues at typical rates did not cause $P$. persimilis mortality 24 hours after application. However, abamectin residue did result in significant mortality to adult $T$. urticae 3,7 , and $14 \mathrm{~d}$ after application. Several other studies have found that exposure to abamectin residues does not have a significant effect on $P$. persimilis survival (Oomen et al., 1991; Shipp et al., 1999; Zhang and Sanderson, 1990). Abamectin causes significant mortality and reduction in the mobility and fecundity of $T$. urticae (Zhang and Sanderson, 1990). Even after 2 weeks, in our experiments abamectin residue killed T. urticae adults. Residual activity of abamectin is likely to decrease more quickly in outdoor environments than indoor environments (Wright et al., 1984). Fourteen-day-old residues from abamectin applications of $3 \mathrm{ppm}$ on cotton grown in greenhouses resulted in $97 \%$ mortality after $72 \mathrm{~h}$ of exposure (Wright et al., 1984). Trials conducted with plants given the same treatment in field conditions caused $47 \%$ mortality with the same exposure (Wright et al., 1984). In our experiments, 14-day-old abamectin residues from applications of 6.25 ppm, with $24 \mathrm{~h}$ of exposure resulted in $45 \%$ T. urticae mortality compared to $6 \%$ mortality on untreated leaf disks in the control.

Abamectin residues can have sublethal effects on $P$. persimilis. Eight days of exposure beginning $1 \mathrm{~h}$ after 4 ppm abamectin applications reduced $P$. persimilis egg laying by as much as 50\% (Zhang and Sanderson, 1990). Exposure of $P$. persimilis to abamectin residues does not decrease egg hatch rate, but feeding on $T$. urticae intoxicated with abamectin can reduce egg production (Zhang and Sanderson, 1990). Despite its sublethal effects on $P$. persimilis, abamectin may be a good candidate for IPM programs because of its high toxicity to $T$. urticae and its relatively low impact on $P$. persimilis.

Mortality of $P$. persimilis caused by Gowan 1725 and hexythiazox residues $1 \mathrm{~d}$ after application was not significantly greater than the control. Our results were consistent with other studies of hexythiazox on $P$. persimilis (Oomen et al., 1991). However, a duration of hexythiazox exposure which is longer than ours may have a negative impact on $P$. persimilis. Residues of Gowan 1725 and hexythiazox may not provide acceptable suppression of adult $T$. urticae in some situations. Gowan 1725 has a chemical structure that is similar to abamectin, but its residues were not effective against adult $T$. urticae. Although hexythiazox has a low toxicity to adult female T. urticae, it still may suppress mite populations by reducing $T$. urticae egg production (Chapman and Marris, 1986). Hexythiazox residues have been shown to have ovicidal effects on Panonychus ulmi $30 \mathrm{~d}$ after application (Pree et. al., 1992). Unlike hexythiazox, Gowan 1725 residue has a short period of adulticidal activity on $T$. urticae under laboratory conditions.

Neem products and parafinic horticultural oils may be a useful part of IPM programs, however their short residual toxicity may not suppress large populations. We found these products to be compatible with $P$. persimilis because they are active for only a short period. Residues from these products did cause mortality to $T$. urticae $24 \mathrm{~h}$ after application, but no mortality thereafter. All neem products may not be equally compatible with $P$. persimilis. Direct application of a neem formulation containing $80 \%$ neem oil at a rate of $3 \%$ was highly toxic to $P$. persimilis and only moderately toxic to T. urticae (Papaioannou-Souliotis et al., 2000). We applied a formulation of $70 \%$ neem oil at a rate of $1.4 \%$. Although the residues had low toxicity to $P$. persimilis, topical applications may be harmful. Horticultural oil can control T. urticae eggs and mobile
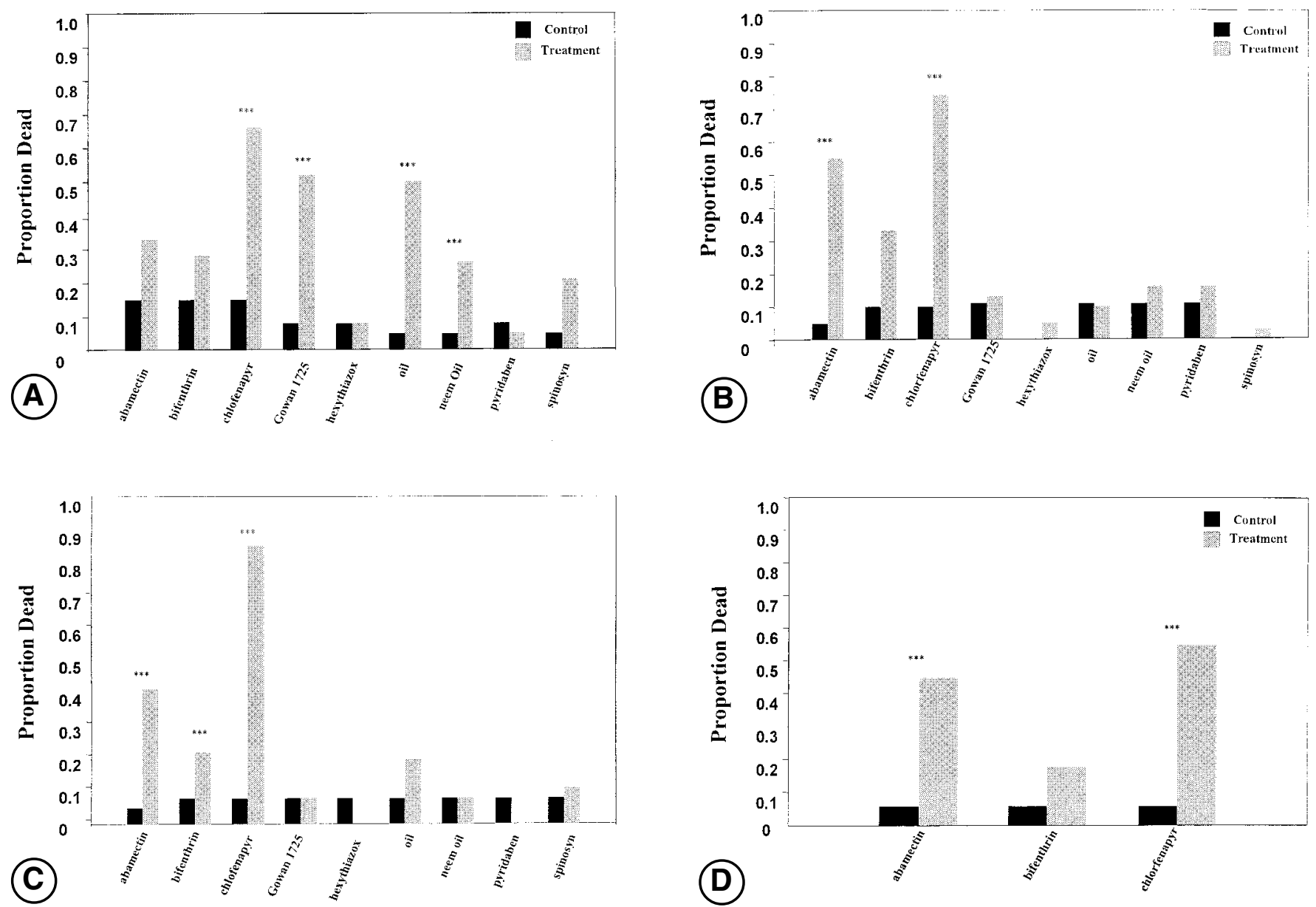

Fig 2. Residue toxicity to Tetranychus urticae (A) 1 day after application, (B) $3 \mathrm{~d}$ after application, (C) $7 \mathrm{~d}$ after application, and (D) $14 \mathrm{~d}$ after application. ***Indicates significant difference $(\alpha=0.05)$ between treatments and control. 
stages (Haitas, 1997) and also reduces female fecundity (Osman, 1997).

Spinosad and pyridaben residues did not cause direct harm to $P$. persimilis or T. urticae. Pratt and Croft (2000) also found that spinosad does not have a highly toxic effect on $P$. persimilis. Formulations of spinosad containing $11.6 \%$ spinosad A and D, can cause $100 \%$ mortatlity when applied directly to mites at 400 ppm (DeAmicis et al., 1997). Our application rate was $181 \mathrm{ppm}$ and residues were allowed to dry before exposing mites. This application rate did not suppress $T$. urticae populations under laboratory conditions (Cote, unpublished data). We recorded $28 \%$ and $30 \%$ mortality after $24 \mathrm{~h}$ of exposure to 1 - and 3 day-old pyridaben residue, respectively. Shipp et al. (1999) found pyridaben to cause $P$. persimilis mortality as high as $71 \% 4 \mathrm{~d}$ after application with $48 \mathrm{~h}$ of exposure under laboratory conditions.

Bifenthrin and chlorfenapyr were toxic to $P$.persimilis up to 2 weeks after treatment, but this prolonged period of residual activity may be useful for controlling high-density populations of T. urticae. Chlorfenapyr provided excellent control of $T$. urticae infestations without short-term population resurgence (Allen and Kharboutli, 1999; Cote, unpublished data). This is the first published account of the effects of chlorfenapyr residues on $P$. persimilis. Our results with bifenthrin are consistent with other studies (Oomen et al., 1991; Pratt and Croft, 2000).

Acaricides tested in this study varied greatly in their toxicity to $P$. persimilis and $T$. urticae adults. Phytoseiulus persimilis releases alone are unlikely to prevent $T$. urticae populations from reaching economic injury levels on ornamental crops (Helle and Sabelis, 1985). Selective use of acaricides may create a favorable situation for release of $P$. persimilis by reducing $T$. urticae to manageable levels, providing that other environmental conditions are suitable. While treatment with acaricides that have long residual toxicity may be required to suppress high-density spider mite populations, their use may promote spider mite resistance. Acaricides that have short residual toxicities can be used in combination with predators to reduce large populations of spider mites, but the timing of application and predator release is critical (Osborne and Petitt, 1985). Applica- tions of insecticidal soap $3 \mathrm{~d}$ after release of $P$. persimilis did not adversely affect predator populations and provided enhanced suppression of spider mite populations (Osborne and Petitt, 1985). Biological control may be enhanced through careful selection of acaricides and releasing predators into the crop once residues are no longer toxic to them.

\section{Literature Cited}

Allen, C.T. and M.S. Kharboutli. 1999. Spider mite control in southeast Arkanasas. Proc. Beltwide Cotton Conf. 2:1185-1186.

Carbonaro, M.A., D.E. Moreland, V.E. Edge, N. Motoyama, G.C. Rock, and W.C. Dauterman. 1986. Studies on the mechanisms of cyhexatin resistance in the twospotted spider mite, Tetranychus urticae (Acari: Tetranychidae). J. Econ. Entomol. 79:576-579.

Chapman, R.B. and J.W.M. Marris. 1986. The sterilizing effect of clofentezine and hexythiazox on female twospotted spider mite. Proc. $39^{\text {th }}$ N.Z. Weed and Pest Control Conf. 39:237240.

DeAmicis, C.V., J.E. Dripps, C.J. Hatton, and L.L. Karr. 1997. Phytochemicals for pest control. Amer. Chem. Soc. J. 658: 144-154.

Haitas, V.C., C.S. Fotiadis, V.A. Bourbos, and M.T. Skoudridakis. 1997. The superior oil Ultrafine. Uses and perspectives. Agro Food Ind. Hi Tech. 8:39-42.

Helle, W. and M.W. Sabelis. 1985. Spider mites: Their biology, natural enemies and control. Volume 1B. Elsevier, Amsterdam.

Huffaker, C.B. 1948. An improved cage for work with small insects. J. Econ. Entomol. 41:648649 .

Johnson, W.T. and H.H. Lyon. 1991. Insects that feed on trees and shrubs. Comstock Publishing and Cornell Univ. Press, Ithaca, N.Y.

Lester, P.J., D.J. Pree, H.M.A. Thistlewood, L.M. Trevisan, and R. Harsen. 1999. Pyrethroid encapsulation for conservation of acarine predators and reduced spider mite (Acari: Tetranychidae) outbreaks in apple orchards. Environ. Entomol. 28:72-80.

Lindquist R.K. 1981. Introduction of predators for insect and mite control on commercial interior plantings. Ohio Florists' Assn. Bul. No. 622.

Munger, Francis. 1942. A method for rearing citrus thrips in the laboratory. J. Econ. Entomol. 35:373-375.

Oomen, P.A., G. Romeijn, and G.L. Wiegers. 1991 Side-effects of 100 acaricides on the predatory mite Phytoseiulus persimilis, collected and evaluated according to the EPPO guideline. Bul. European and Mediterranean Plant Protec- tion organization (OEPP/EPPO) 21:701-712.

Osborne, L.S. and F.L. Petitt. 1985. Insecticidal soap and the predatory mite, Phytoseiulus persimilis (Acari:Phytoseiidae), used in management of the twospotted spider mite (Acari: Tetranychidae) on greenhouse grown foliage plants. J. Econ. Entomol. 78:687-691.

Osman, M.S. 1997. Petroleum oils as a component of integrated pest management of phytophagous mites. Arab Gulf J. Scient. Res. 15:125135

Papaioannou-Souliotis, P., D. MarkouiannakiPrintziou, and D. Zoaki-Malissiova. 2000. Side effects of Neemark (Azadirachta indica A.Juss) and two new vegetable oil forumulations on Tetranychus urticae Koch and its predator Phytoseiulus persimilis Athias-Henriot. Boll. Zool. Agr. Bachic. 32:25-33.

Pratt, P.D. and B.A. Croft. 2000. Toxicity of pesticides registered for use in landscape nurserires to the acarine biological control agent, Neoseiulus fallacis. J. Environ. Hort 18:197201

Pree, D.J., D.B. Marshall, and B.D. McGarvey. 1992. Residual toxicity of dicofol formetanate $\mathrm{HCl}$, propargite, hexythiazox, and clofentezine to European red mite on peach. Can. Ent. 124:59-67.

Sabelis, M.W. 1981. Biological control of twospotted spider mites using phytoseiid predators. Part 1. Modeling the predator-prey interaction at the individual level. Agr. Res. Rpt. No. 910. Wageningen, The Netherlands.

Shipp, J.L., K. Wang, and G. Ferguson. 2000. Residual toxicity of avermectin b1 and pyridaben to eight commercially produced beneficial arthropod species used for control of greenhouse pests. Biol. Control 17:125-131.

Stenseth, C. 1979. Effect of temperature and humidity on the development of Phytoseiulus persimilis and its ability to regulate populations of Tetranychus urticae (Acarina: Phytoseiidae, Tetrancyhidae). Entomoph. 249:311-317.

Trumble, J.T. and J.P. Morse. 1993. Economics of integrating the predaceous mite Phytoseiulus persimilis (Acari: Phytoseiidae) with pesticides in strawberries. J. Econ. Entomol. 86:879-885.

Wright, D.J., I.T.J. Roberts, A. Androher, A. St. J. Green, and R.A. Dybas. 1984. The residual activity of abamectin (MK-936) against Tetranychus urticae (Koch) on cotton. Meded. Fac. Landbouwwet. Rijksuniv. 50:633-637.

Zhang, Z. and J.P. Sanderson. 1990. Relative toxicity of abamectin to the predatory mite Phytoseiulus persimilis (Acari: Phytoseiidae) and twospotted spider mite (Acari: Tetranychidae). J. Econ. Entomol. 83: 17831790 